\title{
ВИРОБНИЧА ПЕРЕВІРКА ЕФЕКТИВНОСТІ ВАКЦИНИ «МАСТИВАК» ПРОТИ КЛІНІЧНИХ ТА СУБКЛІНІЧНИХ МАСТИТІВ
}

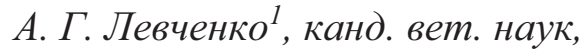 \\ О. В. Фотін ${ }^{2}$ канд. вет.наук, дочент, \\ С. С. Улько ${ }^{2}$, аспірант \\ ${ }^{1}$ Одеський державний аграрний університет, \\ вул. Пантелеймонівська, 13, м. Одеса, 65012, Україна \\ ${ }^{2}$ Сумський національний аграрний університет, \\ вул. Г. Кондратьєва, 160, м. Суми, 40021, Україна
}

При проведенні клінічних випробувань вакцини «Мастивак», корови були розділені на дві групи за принципом аналогів по 10 голів у кожній. Вакцину вводили підшкірно в діляниі середньої ділянки шиї в дозі $5 \mathrm{~cm}^{3}$. Корови першої групи вакииновані двократно з інтервалом 15 днів. Корови другої групи вакцинаиії не піддавались. За коровами вели щоденне клінічне спостереження та щотижневе дослідження зразків молока. У корів другої групи (не вакцинована) були виявлені дві тварини з клінічними ознаками маститу та чотири тварини $з$ ознаками субклінічного маститу. При дослідженні молока корів виявили, що у корів другой групи знижені показники якості молока - клас забрудненості молока 1, 2 та 3 в той час як молоко корів першої групи відповідає вищому класу. ВАКЦИНА.

Ключові слова: МАСТИТ, КЛІНІЧНИЙ МАСТИТ, СУБКЛІНІЧНИЙ МАСТИТ,

Мастит - поліетіологічне захворювання, здебільшого викликане розвитком патогенної мікрофлори, яка потрапляє у тканини вимені. Вакцинація - є ефективним і простим способом боротьби з маститом корів, викликаним $S$. aureus та $E$. coli, а також рядом інших стафілококів (коагулазно-негативних) та паличкоподібних бактерій [1]. Мастит також можуть викликати лістерії, гриби, хламідії, кампілобактерії [2, 3].

Збитки від захворювання корів на мастит становлять 25 - 30 \% від прибутку за здану молочну продукцію по фермі та напряму залежать від кількості корів у дійному стаді. Наприклад, за наявності у стаді 1500 корів загальна сума збитків може сягати понад три млн. грн. на рік [4].

Висока вірулентність збудників захворювання (гемолітичний стрептокок, золотистий стафілокок, Escherichia coli) та низька резистентність корів обумовлюють несприятливий перебіг хвороби і недостатню терапевтичну ефективність етіотропної, патогенетичної та специфічної терапії. Захворювання корів на мастит може закінчуватись по-різному в залежності від патогенності збудника, стану імунної системи організму корів, резистентності тканин вимені [5].

На сучасному етапі розвитку тваринництва та ветеринарної медицини в Україні і за кордоном використовують різного роду біологічно активні речовини, вітаміни, ферменти, гормони, тканинні препарати, препарати на основі прополісу, біостимулятори рослинного походження, а також вакцинні препарати. При їх застосуванні підвищується стійкість організму до несприятливих факторів зовнішнього середовища, зокрема до збудників хвороб [5]. Тому, пошук та створення нових препаратів, які в першу чергу ефективно попереджали виникненню маститів й гарантували б якість молока, на нинішньому етапі $є$ актуальним 
завданням для ветеринарної медицини. До такого препарату доцільно зарахувати вакцину «Мастивак» на основі інактивованих бактеріальних клітин стрептококів, стафілококів, арканобактерій, ешерихій, інактивованих формальдегідом 3 додаванням в якості ад'юванту алюмінію гідроксиду та ізотонічного розчину натрію хлориду до 5 мл.

Метою нашої роботи стало впровадження екологічно безпечних, по відношенню до молока, та ефективних засобів профілактики бактеріальних маститів. Вивчення ефективності застосування вакцини «Мастивак» для профілактики маститу у корів.

Матеріали i методи. Дослідження проводилися на базі клініки Сумського національного аграрного університету на коровах української чорно-рябої породи, різних вікових груп.

Для вивчення ефективності застосування вакцини «Мастивак» корови були розділені на дві групи за принципом аналогів (контрольна та дослідна) по 10 голів у кожній. Корови першої групи були вакциновані вакциною «Мастивак» двократно 3 інтервалом 15 днів. Вакцину вводили підшкірно в ділянці середньої ділянки шиї в дозі $5 \mathrm{~cm}^{3}$. Корови другої групи вакцинації не піддавались. За коровами вели щоденне клінічне спостереження. Кожного тижня проводили дослідження зразків молока.

Вим'я досліджували за допомогою огляду, пальпації та пробного доїння. Оглядом визначали колір і цілісність шкіри, стан волосяного покриву, форму та пропорційність окремих часток вим'я.

Пальпацією встановлювали больову і температурну реакцію молочної залози, іiі консистенцію, наявність і характер ущільнень та інших морфологічних змін у тканині, цистерні і каналі дійки вим'я. Для визначення консистенції, болючості та характеру ущільнень кожну чверть вим'я пальпували окремо шляхом легкого стискання її тканин. Цистерну і канал дійки досліджували шляхом помірного стискання основи дійки, розташовуючи ії між вказівним $\mathrm{i}$ великим пальцями і витягаючи іiї донизу.

Пробним доїнням визначали тонус сфінктера та аномалії дійкового каналу за зусиллям, що прикладається при здоюванні молока.

Для диференціальної діагностики клінічного маститу у корів керувалися класифікацією за А. П. Студенцовим.

Для діагностики субклінічного маститу та для контролю застосовували 2 \%-й розчин мастидину i пробу відстоювання. Діагностування субклінічного маститу проводили двократно, 3 інтервалом 48 год, методом експрес-діагностики із зазначеним реактивом. Двократні позитивні результати давали підставу вважати тварину хворою субклінічним маститом і проводити подальші бактеріологічні дослідження [6].

Для визначення імунологічної реактивності організму корів, брали проби крові із яремної вени від дослідних корів двічі: перед введенням препарату і на 2-гу добу після закінчення досліду, а оглядали тварин щоденно до повного одужання. Водночас із першим взяттям крові у дослідних тварин відбирали кров і в невакцинованих корів.

Кров брали від кожної тварини у дві стерильні пробірки, одна з них - $з$ гепарином (200

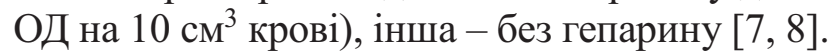

Бактерицидну активність сироватки крові визначали методом фотонефелометрії з тесткультурою Staphylococcus aureus за методикою Слоніма А. А. [9].

Лізоцимну активність сироватки крові визначали фотоелектроколориметричним методом по зміні оптичної щільності середовища в результаті здібності лізоциму крові лізувати тест-культуру Micrococcus lysodeicticus (штам 2655) в 0,5 \% розчині хлориду натрію $(\mathrm{NaCl})$ за методикою Чумаченко В. Е. [10].

Результати й обговорення. Аналіз отриманих даних показав, що профілактична ефективність застосування вакцини «Мастивак» становила 88 \%.

У корів другої групи (не вакцинована) були виявлені дві тварини з клінічними ознаками маститу та чотири тварини з ознаками субклінічного маститу. При дослідженні молока корів 
виявили, що у корів другої групи знижені показники якості молока - клас забрудненості молока 1, 2 та 3 в той час як молоко корів першої групи відповідає вищому класу (табл. 1, 2).

Показники якості молока першої групи (вакцинована)

Таблиия 1

\begin{tabular}{|c|c|c|c|c|c|c|c|c|}
\hline $\begin{array}{c}\text { № } \\
\text { тварини }\end{array}$ & Жир, \% & $\begin{array}{c}\text { Сухий } \\
\text { знежирени } \\
\text { й залишок }\end{array}$ & $\begin{array}{l}\text { Щільність, } \\
\text { *A (27- } \\
32 * A)\end{array}$ & $\begin{array}{c}\text { Додан } \\
\text { а вода, } \\
\text { \% }\end{array}$ & $\begin{array}{c}\text { Температур } \\
\text { a } \\
\text { замерзання } \\
-0,0 * C\end{array}$ & Білок & $\begin{array}{c}\text { Клас бак. } \\
\text { забрудненн } \\
\text { я }\end{array}$ & $\begin{array}{l}\text { Проба } \\
\text { на } \\
\text { мастит }\end{array}$ \\
\hline 1 & 2,10 & 8,78 & 30,7 & 0 & 58,0 & 3,14 & $\mathrm{~B}$ & - \\
\hline 2 & 2,19 & 9,75 & 34,6 & 0 & 64,7 & 3,50 & $B$ & - \\
\hline 3 & 2,62 & 7,90 & 26,7 & 0 & 54,0 & 2,82 & $\mathrm{~B}$ & - \\
\hline 4 & 2,14 & 8,27 & 28,6 & 0 & 54,5 & 2,95 & $\mathrm{~B}$ & - \\
\hline 5 & 5,13 & 8,77 & 28,0 & 0 & 57,0 & 3,16 & $\mathrm{~B}$ & - \\
\hline 6 & 4,20 & 8,44 & 27,5 & 0 & 55,3 & 3,03 & $B$ & - \\
\hline 7 & 4,90 & 8,19 & 27,1 & 0 & 54,7 & 2,95 & $\mathrm{~B}$ & - \\
\hline 8 & 4,13 & 8,20 & 26,9 & 0 & 54,1 & 2,94 & $B$ & - \\
\hline 9 & 5,49 & 7,93 & 27,8 & 0 & 54,9 & 2,86 & $\mathrm{~B}$ & - \\
\hline 10 & 5,72 & 8,15 & 27,0 & 0 & 54,3 & 2,94 & $\mathrm{~B}$ & - \\
\hline
\end{tabular}

Таблиия 2

Показники якості молока другої групи (не вакцинована)

\begin{tabular}{|c|c|c|c|c|c|c|c|c|}
\hline $\begin{array}{c}\text { № } \\
\text { тварини }\end{array}$ & Жир, \% & $\begin{array}{c}\text { Сухий } \\
\text { знежирени } \\
\text { й залишок }\end{array}$ & $\begin{array}{c}\text { щільність, } \\
\text { *А (27- } \\
32 * A)\end{array}$ & $\begin{array}{c}\text { Додан } \\
\text { а вода, } \\
\%\end{array}$ & $\begin{array}{c}\text { Температур } \\
\text { а } \\
\text { замерзання } \\
-0,0 * \text { С }\end{array}$ & Білок & $\begin{array}{c}\text { Клас бак. } \\
\text { забрудненн } \\
\text { я }\end{array}$ & $\begin{array}{c}\text { Проба } \\
\text { на } \\
\text { мастит }\end{array}$ \\
\hline 11 & 4,30 & 8,70 & 28,4 & 0 & 56,9 & 3,13 & 1 & + \\
\hline 12 & 4,87 & 8,33 & 26,4 & 1,90 & 54,5 & 3,00 & 1 & + \\
\hline 13 & 4,47 & 8,72 & 28,4 & 0 & 56,9 & 3,14 & 1 & + \\
\hline 14 & 4,40 & 8,69 & 28,3 & 0 & 56,8 & 3,13 & 2 & ++ \\
\hline 15 & 4,21 & 8,06 & 25,9 & 4,60 & 53,0 & 2,89 & 1 & - \\
\hline 16 & 4,10 & 8,63 & 28,3 & 0 & 56,5 & 3,10 & 1 & - \\
\hline 17 & 5,43 & 8,33 & 25,9 & 2,15 & 54,4 & 3,00 & 3 & +++ \\
\hline 18 & 4,25 & 8,67 & 28,3 & 0 & 56,7 & 3,12 & 2 & - \\
\hline 19 & 3,44 & 7,94 & 26,1 & 5,95 & 52,3 & 2,83 & 3 & +++ \\
\hline 20 & 4,41 & 8,35 & 26,9 & 1,51 & 54,8 & 3,00 & 1 & - \\
\hline
\end{tabular}

При дослідженні лейкограми корів першої та другої групи встановили що у корів 3 ознаками субклінічного маститу кількість лейкоцитів була вища у порівнянні з кількістю лейкоцитів у корів вакцинованої групи (таблиця 3). Показники лейкоцитів у корів з ознаками клінічного маститу були на рівні 9,7 $\pm 0,7$ Г/л.

Збільшення кількості еозинофілів пояснюється сенсибілізуючими властивостями стафілококів. Дані наведені в таблиці 3.

Таким чином, застосування препарату "Мастивак" сприяє нормалізації клітинних показників резистентності.

Матеріали таблиці 4 показують, що бактерицидна та лізоцимна активність сироватки крові корів після вакцинації підвищилась порівняно з такою у невакцинованих корів. Після застосування засобу "Мастивак" у сироватці крові рівень крупномолекулярних та дрібних циркулюючих імунних комплексів знизився, а середніх циркулюючих імунних комплексів мав тенденцію до збільшення. 
Показники лейкограми корів першої та другої груп корів $(\mathrm{M} \pm \mathbf{m}, \mathbf{n}=\mathbf{2 0})$

\begin{tabular}{|c|c|c|c|c|c|c|c|}
\hline \multirow[b]{2}{*}{$\begin{array}{l}\text { Групи } \\
\text { корів }\end{array}$} & \multirow{2}{*}{$\begin{array}{c}\text { К-ть } \\
\text { лейкоцитів, Г/л }\end{array}$} & \multirow[b]{2}{*}{ Базофіли } & \multirow[b]{2}{*}{ Еозинофіли } & \multicolumn{2}{|c|}{ Нейтрофіли } & \multirow[b]{2}{*}{ Лімфоцити } & \multirow[b]{2}{*}{ Моноцити } \\
\hline & & & & $\begin{array}{c}\text { Паличко- } \\
\text { ядерні }\end{array}$ & $\begin{array}{c}\text { Сегменто- } \\
\text { ядерні }\end{array}$ & & \\
\hline $\begin{array}{l}\text { Корови } \\
\text { I групи }\end{array}$ & $5,8 \pm 0,32$ & $\frac{1,3 \pm 0,1}{83,0}$ & $\frac{3,3 \pm 0,9}{203}$ & $\frac{4,4 \pm 0,5}{269,0}$ & $\frac{21,6 \pm 1,2}{1300,1}$ & $\frac{64,7 \pm 1,6}{3887,0}$ & $\frac{4,1 \pm 0,1}{251,0}$ \\
\hline $\begin{array}{l}\text { Корови } \\
\text { II групи }\end{array}$ & $8,6 \pm 0,38$ & $\underline{1,7 \pm 0,1}$ & $\underline{4,3 \pm 1,0 *}$ & $\underline{5,7 \pm 0,9}$ & $\underline{28,6 \pm 1,9 *}$ & $\underline{53,5 \pm 2,4}$ & $4,9 \pm 0,4$ \\
\hline $\begin{array}{l}\text { Субкл. } \\
\text { мастит }\end{array}$ & & 155,5 & 374,1 & 495,9 & 2488,2 & 4749,1 & 433 \\
\hline $\begin{array}{c}\text { Клін. } \\
\text { мастит }\end{array}$ & $9,7 \pm 0,7$ & $\frac{1,4 \pm 0,1}{146,0}$ & $\frac{5,9 \pm 0,4^{*}}{578,2}$ & $\frac{6,0 \pm 0,3^{*}}{588,0}$ & $\frac{34,4 \pm 0,8^{*}}{3371,2}$ & $\frac{47,3 \pm 1,0 *}{4635,4}$ & $\frac{4,8 \pm 0,2}{479,1}$ \\
\hline
\end{tabular}

Примітка: в чисельнику \%; в знаменнику - абсолютна кількість. $\mathrm{P}<0,001$ у відношенні до здорових корів.

Показники ЦІК, БАСК, ЛАСК корів контрольної та дослідної груп $(\mathrm{M} \pm$ m, n = 20)

\begin{tabular}{|c|c|c|c|c|c|}
\hline \multirow{2}{*}{ Групи корів } & \multicolumn{3}{|c|}{ Концентрація ЦІК, од } & \multirow{2}{*}{ БАСК, \% } & \multirow{2}{*}{ ЛАСК, \% } \\
\hline & крупні & середні & дрібні & & \\
\hline Тварини 1 групи (вакциновані) & $11,4 \pm 4,4$ & $66,6 \pm 8,3$ & $189 \pm 23,3$ & $67,7 \pm 1,2$ & $23,3 \pm 2,0$ \\
\hline 3 клін. Перебігом & $35,1 \pm 1,3^{*}$ & $63,1 \pm 3,2^{*}$ & $217,4 \pm 7,1$ & $66,1 \pm 1,7^{*}$ & $15,8 \pm 1,6$ \\
\hline 3 субклін. Перебігом & $40,1 \pm 1,9$ & $64,9 \pm 4,2^{*}$ & $223,3 \pm 6,4$ & $61,1 \pm 2,4^{*}$ & $14,9 \pm 2,1$ \\
\hline
\end{tabular}

Примітка: * $\mathrm{P}<0,001$.

Аналіз даних таблиці 4 показує, що у корів, хворих на мастит з субклінічною та клінічною формами, спостерігається зниження БАСК та ЛАСК крові, що супроводжується пригніченням захисних сил організму.

Результати досліджень концентрації ЦІК у крові корів, хворих на субклінічний мастит, показали, що в сироватці крові було найбільше дрібних ЦІК. Їх кількість в 1,5 разів перевищувала показники здорових тварин. Крупних ЦІК у 3,5 раза більше.

При клінічній формі маститу кількість дрібних ЦІК у 1,5 рази, а великих - у 3 рази більше порівняно із здоровими. Це вказує на те, що захворювання корів на мастит супроводжується пригніченням захисних сил організму.

Після застосування вакцини "Мастивак" у дозі 5 см³ з інтервалом 15 діб спостерігали такі зміни картини білої крові у корів: збільшення загальної кількості лейкоцитів при субклінічній та клінічній формі, а також збільшення абсолютної кількості еозинофілів, паличкоядерних та сегментоядерних нейтрофілів.

\section{В И С Н О В К И}

1. Таким чином можна зробити висновок, що вакцина «Мастивак» надійно профілактує виникнення субклінічних та клінічних маститів і може використовуватися у профілактичних заходах з метою попередження маститів корів у господарствах.

2. БАСК та ЛАСК корів першої групи вірогідно вище, від корів - другої групи.

3. Проведені дослідження свідчать про високу ефективність вакцини «Мастивак», що дозволяє значно підвищити якість молока та заощадити на лікуванні.

Перспективи досліджень. За результатами досліджень зробити доповнення до листівки-вкладки та іншої технічно-нормативної документації для реєстраційного досьє 3 метою використання для профілактичних заходів препаратів "Мастивак". 


\title{
PRODUCTION INSPECTION OF EFFICIENCY OF VACCINE "MASTIVAC" AGAINST CLINICAL AND SUBCLINICAL MASTITIS IN COWS
}

\author{
A. Levchenko ${ }^{1}$, O. Fotin ${ }^{2}$, E. Ylko ${ }^{2}$ \\ ${ }^{1}$ Odessa State Agrarian University, \\ 13, Pantelejmonovska str., Odessa, 65012, Ukraine \\ ${ }^{2}$ Sumy National Agrarian University \\ 160, G. Kondratieva str., Sumy, 40021, Ukraine
}

S U M M A R Y

Mastitis is a factor disease, which pathogens are present permanently in organisms of animals - obligatory hosts. The conditions for the disease development are disorders of symbiotic balance in interspecies relations between pathogen and host, change in pathogen genotype, and stress effect on the animal organism. The principal law of epizootic process is the law of obligatness. The disturbance in this law balance is a trigger for the development of corresponding factor disease.

During the evolution process between an organism and various microbial species, a dynamic balance is created, which is controlled by the immune system and certain competitiveness between various microorganisms' species. Many diseases are started because the balance of useful bacterial is disturbed a body, which causes decreases of immune protection.

Therefore, research and development of new preparations, which in the first place would prevent bacterial mastitis and guarantee milk quality is at present an important task for veterinary medicine. One of such preparations is vaccine "Mastivac" on the basis of inactivated bacterial cells of Streptococci, Staphylococci, Arcanobacteria, Escherichia inactivated by formaldehyde with added adjuvant aluminum hydroxide and isotonic sodium chloride solution to the volume $5 \mathrm{ml}$.

During clinical studies of "Mastivac" vaccine among 10 non-vaccinated cows, the researchers discovered two animals with clinical signs of mastitis and four animals with signs of subclinical mastitis. The tests of the cow's milk showed that the milk from non-vaccinated cows had lowered parameters of milk quality - milk contamination classes 1,2 and 3, while the milk from vaccinated cows corresponded to the highest class and had a negative result for mastitis test.

Studying of leucograms in cows of the non-vaccinated group revealed that in cows with subclinical mastitis the leucocytes count was higher comparing to leucocytes count in the vaccinated group. Leucocytes count in cows with signs of clinical mastitis was about $9.7 \pm 0.7 \mathrm{~g} / 1$, while Blood Serum Bactericidal Activity and Blood Serum Lysozyme Activity in vaccinated cows were significantly higher.

The efficiency of "Mastivac" vaccine allows improving reliably milk quality (decreasing the milk content of somatic cells) and rendering an economic profit, cutting down expenses for treatment, decreasing subclinical and clinical mastitis forms, and improving the immune status in cows.

Keywords: MASTITIS, CLINICAL MASTITIS, SUBCLINICAL MASTITIS, VACCINE.

\section{ПРОИЗВОДСТВЕННАЯ ПРОВЕРКА ЭФФЕКТИВНОСТИ ВАКЦИНЫ «МАСТИВАК» ПРОТИВ КЛИНИЧЕСКИХ И СУБКЛИНИЧЕСКИХ МАСТИТОВ}

\author{
А. Г. Левченко ${ }^{1}$, А. В. Фотин ${ }^{2}$, Е. С. Улько
}

Одесский государственный аграрный университет, ул. Пантелеймоновская, 13, г. Одесса, 65012, Украина

Сумской национальный аграрный университет ул. Г. Кондратьева, 160, г. Сумы, 40021, Украина 


\section{А Н Н О Т А ЦИ Я}

При проведении клинических испытаний вакцины «Мастивак», коровы были разделены на две группы по принципу аналогов по 10 голов в каждой. Вакцину вводили подкожно в области средней области шеи в дозе $5 \mathrm{~cm}^{3}$. Коровы первой группы вакцинированы двукратно с интервалом 15 дней. Коровы второй группы вакцинации не подвергались. За коровами вели ежедневное клиническое наблюдение и еженедельное исследование образцов молока. У коров второй группы (не вакцинированных) было обнаружено две коровы с клиническими признаками мастита и четыре - с признаками субклинического мастита. При исследовании молока коров обнаружили, что у коров второй группы снижены показатели качества молока - класс загрязненности молока 1, 2 и 3 в то время как молоко коров первой группы соответствует высшему классу.

Ключевые слова: МАСТИТ, КЛИНИЧЕСКИЙ МАСТИТ, СУБКЛИНИЧЕСКИЙ МАСТИТ, ВАКЦИНА.

\section{Л I T E P A T У P A}

1. Досвід боротьби з маститом корів в Україні за допомогою вакцини Старвак. Т. Найкус. Сучасна ветеринарна медицина № 4, 2013. - с. 42 - 44.

2. Зупинить крадія молока. Здоров’я тварин і ліки, № 11. 2015. - с. 14 - 15.

3. Тези доповідей XV з'їзду Товариства мікробіологів України ім. С.М. Виноградського, (11- 15 вересня 2017 р. м. Одеса). Львів, 2017. С. 178.

4. Альфа і омега здоров'я нації. Здоров'я тварин і ліки. № 12. 2016. - с. $10-12$.

5. Левченко А. Г. Особливості прояву маститу у корів у господарствах з різними технологіями та розробка комплексних профілактично-лікувальних заходів: дис. на здобуття наук. ступеня канд. вет. наук: спец. 16.00.03 "Ветеринарна мікробіологія, епізоотологія, інфекційні хвороби та імунологія" / А.Г.Левченко. - Київ, 2015. - 20 с.

6. Краевский А. И. Бактериальный мастит у коров : монография / А. И. Краевский, М. В. Рубленко, Г. П. Дюльгер. - Сумы, 2014. - С.12 - 29.

7. Методи імунологічних досліджень у лабораторіях ветеринарної медицини / В. М. Івченко, М. С. Павленко, О. І. Горбатюк та ін. - Біла Церква, 2003. - 79 с.

8. Казмірчук В. С. Клінічна імунологія і алергологія / В. С. Казмірчук, Л. В. Ковальчук. - Вінниця : Нова книга, 2006. - С. 267 - 275.

9. Слонім A. A. Визначення бактерицидної активності сироватки крові і лімфи / А. А. Слонім, Ю. Д. Толчеев // Лабораторна справа. -1989. - № 7. - С.65 - 66.

10. Чумаченко B. E. Методические рекомендации по определению естественной резистентности у сельскохозяйственных животных для ветеринарных специалистов / В. Е. Чумаченко, В. С. Сичкарь, Ю. В. Оленич. - К. : УСХА, 1992. - С. 36 - 47.

\section{References}

1. The experience of fighting mastitis of cows in Ukraine with the help of the Starvak vaccine. T. Nykus Modern Veterinary Medicine № 4, 2013. - p. 42 - 44. (in Ukrainian).

2. Stop the milk steal. Health of Animals and Medicine, No. 11. 2015. - p. 14 - 15. (in Ukrainian).

3. Abstracts of reports XVth congress of Vinogradskyi society of microbiologists of Ukraine (2017), September 11-15. Lviv, SPOLOM, 2017. P. 178. (in Ukrainian).

4. Alpha and omega health of the nation. Health of animals and medicine. No. 12. 2016. - p. 10 - 12. (in Ukrainian). 
5. Levchenko A.G. Features of the manifestation of mastitis in cows at farms with different technologies and the development of comprehensive preventive and curative measures: dis. for the sciences. Degree Candidate vet Sciences: special 16.00.03 "Veterinary Microbiology, Epizootology, Infectious Diseases and Immunology" / A.G.Levchenko. - Kyiv, 2015. - 20 p. (in Ukrainian).

6. Kraevskii AI Bacterial mastitis in cows: monograph / AI Kraevskii, MV Rublenko, GPP Dyulger. - Sumy, 2014. - C.12 - 29. (in Ukrainian).

7. Methods of immunological research in laboratories of veterinary medicine / V.M.Ivchenko, M.S. Pavlenko, A.I. Gorbatyuk and others. - Belaya Tserkov, 2003. - 79 p. (in Ukrainian).

8. Kazmirchuk V.Ye. Clinical immunology and allergology / V. Ya. Kazmirchuk, L.V. Kovalchuk. - Vinnytsya: New Book, 2006. - P. 267-275. (in Ukrainian).

9. Slonim AA Determination of bactericidal activity of serum of blood and lymph / A. Slonim, Yu. D. Tolcheev // Laboratory case. -1989 - No. 7. - P.65 - 66. (in Ukrainian).

10. Chumachenko V.E. Methodical recommendations on determination of natural resistance in agricultural animals for veterinary specialists / V.E. Chumachenko, V.S. Sichkar, Yu.V. Olenich. - K.: USCA, 1992. - P. 36 - 47. (in Ukrainian).

Рецензент - С. І. Улизько, к. вет. н., доцент, Одеський ДАУ.

УДК 577.1:612.015

doi: 10.36359/scivp.2019-20-2.13

\title{
МОРФОЛОГІЧНІ ПОКАЗНИКИ КРОВІ ЩУРІВ ЗА УМОВ ОКСИДАЦІЙНОГО СТРЕСУ ТА ЗА ДІЇ КОРМОВОЇ ДОБАВКИ «БУТАСЕЛМЕВІТ-ПЛЮС»
}

\author{
T. B. Мартишук ${ }^{1}$, аспірант, \\ Б. В. Гутийㄹ, д-р вет. наук, професор \\ ${ }^{1}$ Інститут біології тварин НААН, \\ вул. В. Стуса, 38, 79000, м. Львів, Україна \\ ${ }^{2}$ Львівський національний університет ветеринарної медицини та біотехнологій \\ імені С.3. Гжицького, \\ вул. Пекарська, 50, м. Львів, 79010, Україна
}

\begin{abstract}
Вільнорадикальне окиснення відіграє надзвичайно важливу роль у розвитку багатьох патологічних прочесів. Отруєння експериментальних тварин тетрахлорметаном за морфологічною картиною та біохімічними змінами близьке до гострих уражень печінки різної етіології у людини та тварин. Саме тому у нашій роботі використано класичну модель ушкодження субклітинних мембран гепатоиитів та розвитку оксидаційного стресу на основі застосування тетрахлорметану. Метою роботи було вивчити морфологічні показники крові щурів за умов оксидачійного стресу та за дї кормової добавки «Бутаселмевіт-плюс». Дослідження проводили на білих статевозрілих молодих щурах-самиях лінії Вістар, масою тіла 180-200 2, яких утримували на стандартному раціоні інститутського віварію Державного науково-дослідного контрольного інституту ветеринарних препаратів та кормових добавок. Тварин було поділено на три групи по 20 тварин у кожній: 1-ша група (К)
\end{abstract}

